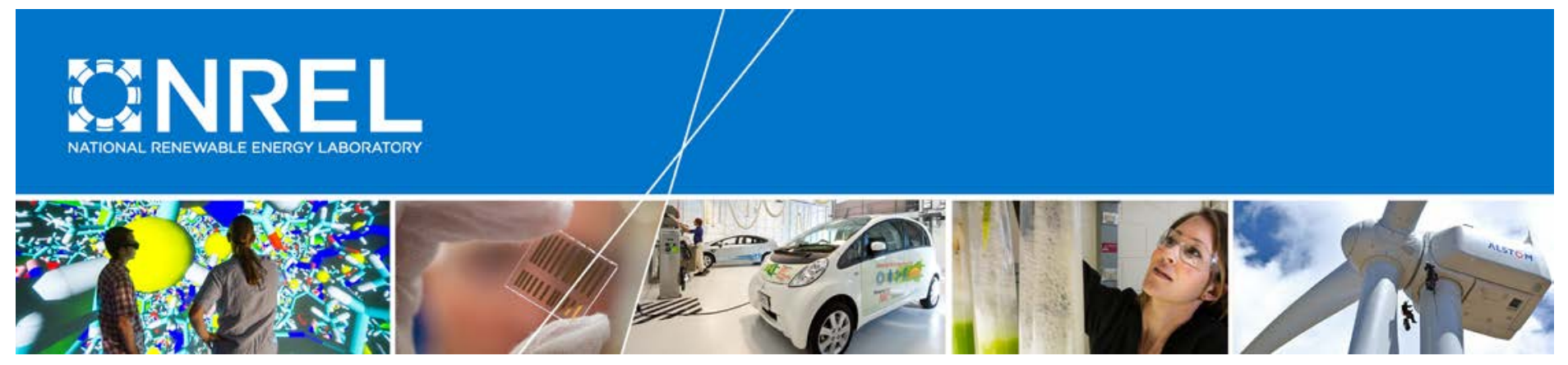

\title{
Hydrogen Financial Analysis Scenario Tool (H2FAST): Web Tool User's Manual
}

B. Bush, M. Penev, and M. Melaina National Renewable Energy Laboratory

J. Zuboy

Independent Consultant

NREL is a national laboratory of the U.S. Department of Energy Office of Energy Efficiency \& Renewable Energy Operated by the Alliance for Sustainable Energy, LLC

This report is available at no cost from the National Renewable Energy Laboratory (NREL) at www.nrel.gov/publications.

Technical Report

NREL/TP-5400-64020

May 2015

Contract No. DE-AC36-08GO28308 


\section{Hydrogen Financial Analysis Scenario Tool (H2FAST): Web Tool User's Manual}

B. Bush, M. Penev, and M. Melaina National Renewable Energy Laboratory

J. Zuboy Independent Consultant

Prepared under Task No. HT12.2A10

NREL is a national laboratory of the U.S. Department of Energy Office of Energy Efficiency \& Renewable Energy Operated by the Alliance for Sustainable Energy, LLC

This report is available at no cost from the National Renewable Energy Laboratory (NREL) at www.nrel.gov/publications.

National Renewable Energy Laboratory 15013 Denver West Parkway Golden, CO 80401 303-275-3000 • www.nrel.gov

\section{Technical Report}

NREL/TP-5400-64020

May 2015

Contract No. DE-AC36-08GO28308 


\title{
NOTICE
}

This report was prepared as an account of work sponsored by an agency of the United States government. Neither the United States government nor any agency thereof, nor any of their employees, makes any warranty, express or implied, or assumes any legal liability or responsibility for the accuracy, completeness, or usefulness of any information, apparatus, product, or process disclosed, or represents that its use would not infringe privately owned rights. Reference herein to any specific commercial product, process, or service by trade name, trademark, manufacturer, or otherwise does not necessarily constitute or imply its endorsement, recommendation, or favoring by the United States government or any agency thereof. The views and opinions of authors expressed herein do not necessarily state or reflect those of the United States government or any agency thereof.

This report is available at no cost from the National Renewable Energy Laboratory (NREL) at www.nrel.gov/publications.

Available electronically at SciTech Connect http:/www.osti.gov/scitech

Available for a processing fee to U.S. Department of Energy and its contractors, in paper, from:

\author{
U.S. Department of Energy \\ Office of Scientific and Technical Information \\ P.O. Box 62 \\ Oak Ridge, TN 37831-0062 \\ OSTI http://www.osti.gov \\ Phone: 865.576.8401 \\ Fax: 865.576.5728 \\ Email: reports@osti.gov
}

Available for sale to the public, in paper, from:

\author{
U.S. Department of Commerce \\ National Technical Information Service \\ 5301 Shawnee Road \\ Alexandra, VA 22312 \\ NTIS http://www.ntis.gov \\ Phone: 800.553 .6847 or 703.605 .6000 \\ Fax: 703.605.6900 \\ Email: orders@ntis.gov
}




\section{Acknowledgments}

This work is funded by the U.S. Department of Energy (DOE) Fuel Cell Technologies Office in the Office of Energy Efficiency and Renewable Energy. The authors would like to acknowledge the feedback and guidance received from members of the H2USA Investment and Finance working group, including Fred Joseck (DOE), Bill MacLeod (Hyundai Motor Group), and Mike Curry (Curry Co.). The development of H2FAST has also benefited from more general input and review comments on predecessor analysis frameworks, as well as the H2FAST tool itself, provided by Sanjeeva Senanayake (Welford Energy), Michael Levy (Aaqius), Tyson Eckerle (GoBiz, California Governor's Office), Remy Garderet (Energy Independence Now), and Ricardo Bracho (National Renewable Energy Laboratory). 


\section{Table of Contents}

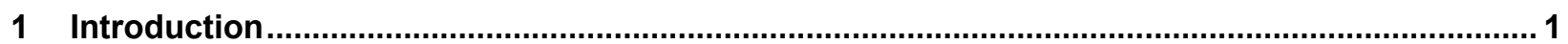

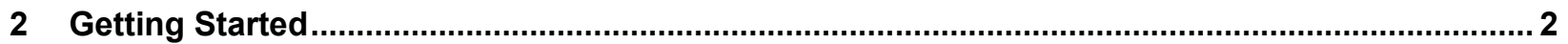

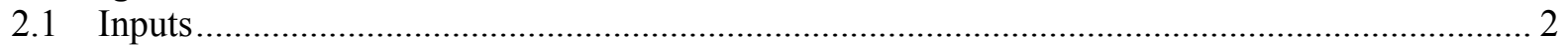

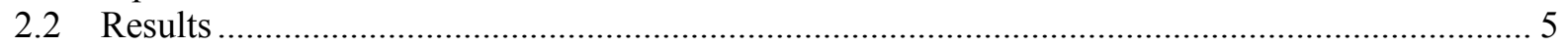

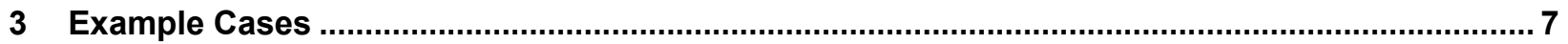

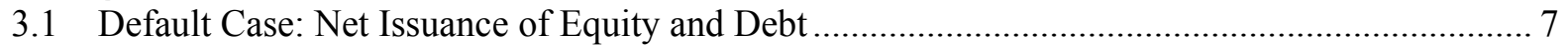

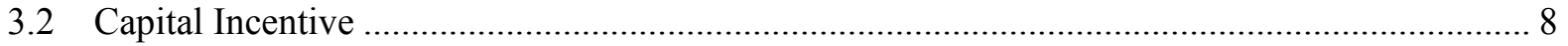

3.3 Production Incentive Instead of Capital Incentive …............................................................ 9

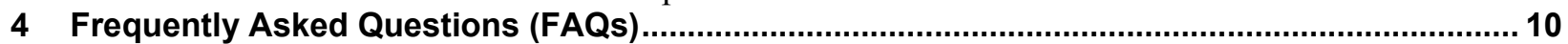

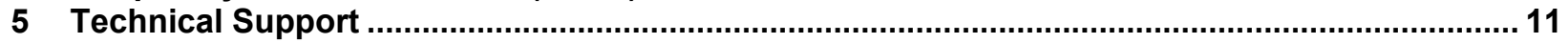

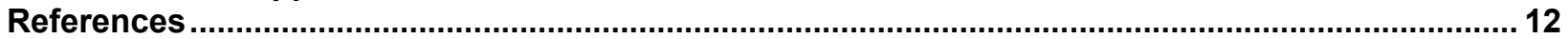

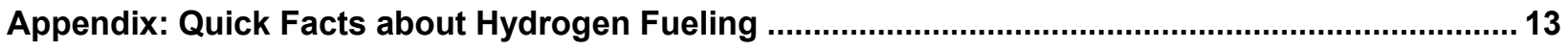




\section{Introduction}

The Hydrogen Financial Analysis Scenario Tool (H2FAST) provides a quick and convenient indepth financial analysis for hydrogen fueling stations. This manual describes how to use the H2FAST web tool, which is one of three H2FAST formats developed by the National Renewable Energy Laboratory (NREL). Although all of the formats are based on the same financial computations and conform to generally accepted accounting principles (FASAB 2014, Investopedia 2014), each format provides a different level of complexity and user interactivity.

The web tool is the simplest to use. As this manual illustrates, web users can quickly vary approximately 20 input values. The results are basic financial performance parameters such as investor cash flow, internal rate of return, and the break-even sale price of hydrogen. It is also possible for users to embed the H2FAST web tool on their own website.

The next most complex format is an interactive Microsoft Excel spreadsheet, which can be downloaded at www.nrel.gov/hydrogen/h2fast/. The H2FAST spreadsheet offers basic and advanced user interface modes for modeling individual stations or groups of up to 10 stations. It provides users with detailed annual finance projections in the form of income statements, cash flow statements, and balance sheets; graphical presentation of financial performance parameters for 65 common metrics; life-cycle cost breakdown for each analysis scenario; and common ratio analysis results such as debt/equity position, return on equity, and debt service coverage ratio.

Finally, the most complex and customizable format is available as part of SERA-NREL's Scenario Evaluation, Regionalization, and Analysis Model — and will be available at http://developer.nrel.gov/. This format is designed for expert users. It accepts user-defined input files and is ideal for examining large numbers of scenarios quickly, for example, to perform sensitivity analyses. 


\section{Getting Started}

To access the H2FAST web tool, go to www.nrel.gov/hydrogen/h2fast/. Beneath the introductory text, you will see the tool's interface, with user input fields on the left and output charts and values on the right (Figure 1). The values shown are default values based on typical station installation and expected financial conditions. To return to these default values at any time, click the "Reset Inputs" button below the interface. The "About" button provides general information about the tool and links to H2FAST documentation, and the blue "i" icons provide tooltips describing the input data fields next to them.

\subsection{Inputs}

Most of the user input values can be changed using a slider bar (by clicking and dragging the small box across the bar) or by manually entering numbers into the input field. When you manually enter a number, you must press the "enter" or "tab" keys or click any other input field to refresh the results using that new value.

The inputs are divided into three sections. The station inputs define your model hydrogen station. The scenario inputs characterize the station's available incentives, incidental revenue, and hydrogen, electricity, and natural gas costs. The financing inputs define the interest rate for debt financing as well as the debt-to-equity ratio. Table 1 defines all of the inputs and indicates whether the station return on investment (ROI) increases or decreases with an increase in each input's value. (A more extensive set of inputs, such as the rent of land and other costs, can be adjusted by users of the interactive Microsoft Excel spreadsheet, which can be downloaded at www.nrel.gov/hydrogen/h2fast/.)

The station input fields for long-term station utilization, vehicle refills, hydrogen per refill, and total capacity are interdependent and linked. For example, using the default values, the total capacity is $250 \mathrm{~kg} /$ day, and there are 43.75 vehicle refills per day at $4 \mathrm{~kg}$ per refill. This yields a station utilization of $70 \%$ as follows: (43.75 refills/day $\times 4 \mathrm{~kg} / \mathrm{refill}) \div 250 \mathrm{~kg} /$ day $=70 \%$. If you keep the total capacity value constant, changing the value for station utilization will automatically change the value for vehicle refills — and vice versa - to maintain the mathematical relationship between these two values and the values for total capacity and hydrogen per refill. Changing the value for hydrogen per refill will automatically change the value for station utilization but not for vehicle refills, and the value for hydrogen per refill is not automatically changed by changing any of the other values. Changing only the value for total capacity will change the value for station utilization but not for the other two values. Typically, station utilization will not be $100 \%$ because of needs to respond to daily and seasonal variations in demand and for reserve capacity.

Clicking "Reset Inputs" returns all of the inputs to the default values present when you first visited the web page.

H2FAST does not assume a particular station configuration, refueling pressure, or state of technological maturity. The tool is intended to be flexible so that users can input station cost assumptions for whatever system is of interest. H2FAST is not a cost estimation tool. Guidance on appropriate values for station costs (capital equipment, etc.) is available in Melaina and Penev (2013) as well as in Argonne National Laboratory's Hydrogen Refueling Station Analysis Model 
(HRSAM) (ANL 2015) and the DOE Hydrogen Analysis (H2A) forecourt production case studies (DOE 2015). The U.S. Energy Information Administration's Annual Energy Outlook is a useful source for forecasts of electricity and natural gas prices (EIA 2015).

Additional information on hydrogen station network planning can be found within web resources provided by the California Fuel Cell Partnership (www.fuelcellpartnership.org/), the H2USA public-private partnership (http://h2usa.org/), and the California Energy Commission's Alternative and Renewable Fuel and Vehicle Technology Program (www.energy.ca.gov/drive/projects). Relevant near-term hydrogen station finance and incentive analyses have also been conducted by Energy Independence Now (www.einow.org/reports.html). The Alternative Fuels Data Center's Station Locator (www.afdc.energy.gov/locator/stations/) shows current hydrogen station locations in the United States, and Ludwig Bolkow Systemtechnik GmbH (www.netinform.net/h2/H2Stations/) maintains a map of worldwide hydrogen stations.

\begin{tabular}{|c|c|c|c|}
\hline \multicolumn{2}{|l|}{ H2FAST } & \multicolumn{2}{|r|}{ (2) About } \\
\hline \multicolumn{4}{|l|}{ Station Inputs } \\
\hline Installation time [months] & (1) & 18 & \\
\hline Demand ramp-up [years] & (1) & 2 & 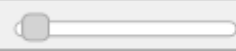 \\
\hline Station type: Delivered Gaseous H2 & $\checkmark$ & & \\
\hline Long-term station utilization [\%]: & (1) & 70 & \\
\hline Vehicle refills [refills/day]: & (1) & 43.75 & \\
\hline Hydrogen per refill [kg]: & (1) & 4 & \\
\hline Total capacity [kg/day]: & (1) & 250 & \\
\hline Hydrogen price [\$ $/ \mathrm{kg}]$ : & (1) & 10 & \\
\hline Equipment capital cost [S]: & (1) & $1,031,846$ & \\
\hline Total installation cost [\$\$]: & (1) & 237,325 & $\square$ \\
\hline $\begin{array}{l}\text { Planned and unplanned } \\
\text { O\&M costs [\$/yr]: }\end{array}$ & (1) & 95,316 & \\
\hline \multicolumn{4}{|l|}{ Scenario Inputs } \\
\hline Capital incentive [S/station]: & (1) & 0 & \\
\hline Initial production incentive [\$/station]: & (1) & 0 & \\
\hline $\begin{array}{l}\text { Annual decrement of production } \\
\text { incentive [\$/station]: }\end{array}$ & (1) & 0 & \\
\hline Incidental revenue [\$/year] & (1) & 0 & $\mathrm{O}$ \\
\hline Cost of delivered hydrogen [S/kg] & (1) & 5.5 & 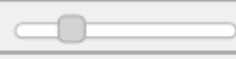 \\
\hline Cost of electricity [\$/kWh] & (1) & 0.12 & 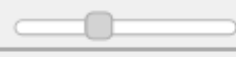 \\
\hline Cost of natural gas [S/mmBTU] & (1) & 8 & $\hookrightarrow \mathrm{O}$ \\
\hline \multicolumn{4}{|l|}{ Financing Inputs } \\
\hline Debt interest rate [\%]: & (1) & 6 & \\
\hline Minimum debt to equity ratio: & (1) & 0.5 & 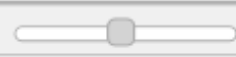 \\
\hline
\end{tabular}

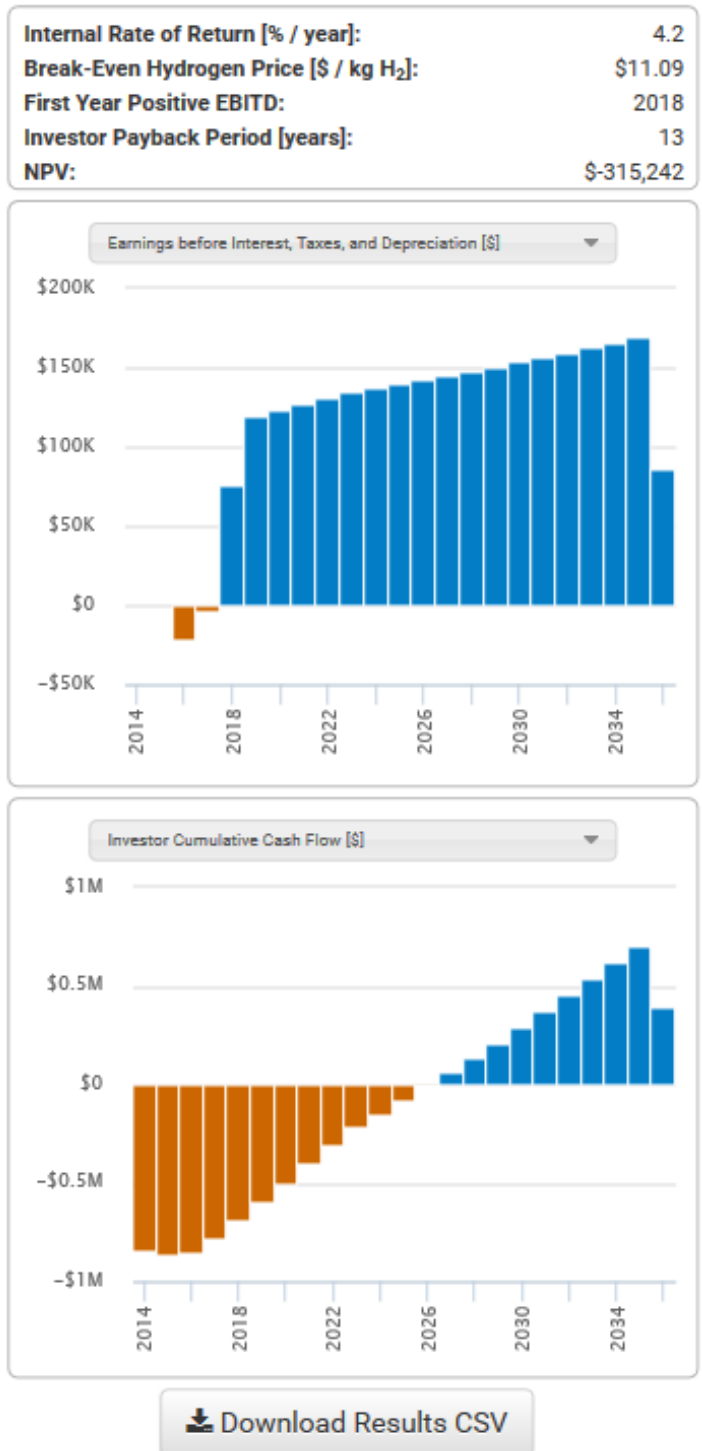

Figure 1. Web-based H2FAST interface with user input fields (left) and results (right) 
Table 1. Web-Based H2FAST Input Definitions and Impact of Input Increase on Station ROI

\begin{tabular}{|c|c|c|c|}
\hline \multicolumn{4}{|c|}{ Station Inputs } \\
\hline Input & Units & Description & $\begin{array}{l}\text { Impact } \\
\text { of } \\
\text { Increase } \\
\text { on ROI }\end{array}$ \\
\hline Installation time & months & $\begin{array}{l}\text { Integer number of months from start of station construction to start of } \\
\text { operation. }\end{array}$ & $\downarrow$ \\
\hline $\begin{array}{l}\text { Demand ramp- } \\
\text { up }\end{array}$ & years & Years it takes demand to reach its long-term maximum. & $\downarrow$ \\
\hline Station type & - & $\begin{array}{l}\text { Four types: delivered gaseous/liquid hydrogen, onsite } \\
\text { electrolysis/steam methane reforming. }\end{array}$ & - \\
\hline $\begin{array}{l}\text { Long-term } \\
\text { station } \\
\text { utilization }\end{array}$ & $\%$ & $\begin{array}{l}\text { Stations may require reserve capacity for network robustness for events } \\
\text { such as nearby station maintenance downtimes and special traffic } \\
\text { events. Default of } \sim 70 \% \text { advised. }\end{array}$ & $\uparrow$ \\
\hline Vehicle refills & refill/day & Number of vehicles refueling at the station per day. & $\uparrow$ \\
\hline $\begin{array}{l}\text { Hydrogen per } \\
\text { refill }\end{array}$ & $\mathrm{kg}$ & Quantity of hydrogen per vehicle refill. & $\uparrow$ \\
\hline Total capacity & kg/day & $\begin{array}{l}\text { Average daily dispensing capacity such that station can adequately } \\
\text { refuel cars during peak-demand days throughout year. }\end{array}$ & $\uparrow$ \\
\hline Hydrogen price & $\$ / \mathrm{kg}$ & $\begin{array}{l}\text { Total cost to end customer including all transaction costs such as credit } \\
\text { card fees and sales taxes. Price is for beginning of project. }\end{array}$ & $\uparrow$ \\
\hline $\begin{array}{l}\text { Equipment } \\
\text { capital cost }\end{array}$ & $\$$ & $\begin{array}{l}\text { Cost of equipment only, not including other expenses such as } \\
\text { engineering, permitting, and installation. Model assumes salvage value } \\
\text { equals decommissioning costs for end-of-life treatment. }\end{array}$ & $\downarrow$ \\
\hline $\begin{array}{l}\text { Total } \\
\text { installation cost }\end{array}$ & $\$$ & $\begin{array}{l}\text { All installation costs such as engineering, permitting, lot/utility upgrades, } \\
\text { etc. }\end{array}$ & $\downarrow$ \\
\hline $\begin{array}{l}\text { Planned and } \\
\text { unplanned } \\
\text { O\&M costs }\end{array}$ & $\$ / y r$ & $\begin{array}{l}\text { Levelized annual maintenance costs for planned/unplanned equipment } \\
\text { servicing and overhauls. Assumed to be non-depreciable. }\end{array}$ & $\downarrow$ \\
\hline \multicolumn{4}{|c|}{ Scenario Inputs } \\
\hline $\begin{array}{l}\text { Capital } \\
\text { incentive }\end{array}$ & \$/station & $\begin{array}{l}\text { Provided at beginning of project (during financing phase, Dec. } 31 \text {, the } \\
\text { year before construction begins). Can be grant or investment tax credit. }\end{array}$ & $\uparrow$ \\
\hline $\begin{array}{l}\text { Initial } \\
\text { production } \\
\text { incentive }\end{array}$ & \$/station & $\begin{array}{l}\text { Performance-based incentive beginning the month of station } \\
\text { commissioning. Can be grant or production tax credit. }\end{array}$ & $\uparrow$ \\
\hline $\begin{array}{l}\text { Annual } \\
\text { decrement of } \\
\text { production } \\
\text { incentive }\end{array}$ & \$/station & $\begin{array}{l}\text { Amount by which annual operating incentives are reduced each year. } \\
\text { Allows this revenue stream to be ramped to zero by fixed annual } \\
\text { amount. }\end{array}$ & $\downarrow$ \\
\hline $\begin{array}{l}\text { Incidental } \\
\text { revenue }\end{array}$ & \$/year & $\begin{array}{l}\text { Other station revenue enhancements from presence of hydrogen, } \\
\text { expressed as (marginal revenue - marginal expenses). }\end{array}$ & $\uparrow$ \\
\hline $\begin{array}{l}\text { Cost of } \\
\text { delivered } \\
\text { hydrogen }\end{array}$ & $\$ / \mathrm{kg}$ & $\begin{array}{l}\text { Delivered hydrogen price defined at start of project (not at start of } \\
\text { operation). }\end{array}$ & $\downarrow$ \\
\hline $\begin{array}{l}\text { Cost of } \\
\text { electricity }\end{array}$ & $\$ / k W h$ & $\begin{array}{l}\text { Electricity price for hydrogen production (for reformers and } \\
\text { electrolyzers), compression, and pre-cooling. }\end{array}$ & $\downarrow$ \\
\hline $\begin{array}{l}\text { Cost of natural } \\
\text { gas }\end{array}$ & $\$ / m m B t u$ & Cost of natural gas delivered to stations. & $\downarrow$ \\
\hline \multicolumn{4}{|c|}{ Financing Inputs } \\
\hline $\begin{array}{l}\text { Debt interest } \\
\text { rate }\end{array}$ & $\%$ & For loan and revolving debt calculations. & $\downarrow$ \\
\hline $\begin{array}{l}\text { Minimum debt } \\
\text { to equity ratio }\end{array}$ & - & Initial financing capital structure (ratio of debt to equity financing). & $\uparrow$ \\
\hline
\end{tabular}




\subsection{Results}

As shown on the right side of Figure 1, two of the results are presented as graphs. By default, these are earnings before interest, taxes, and depreciation (EBITD) and cumulative cash flow. Table 2 shows all of the options for output graphs, which you can select from the drop-down menu above each graph box. When you hover over the bars on the graphs, the values for individual years will appear.

Table 2. Web-Based H2FAST Output Graphs

\begin{tabular}{|c|c|}
\hline Graph Title & Description \\
\hline Cost of Goods Sold $\left[\$ / \mathrm{kg} \mathrm{H}_{2}\right]$ & $\begin{array}{l}\text { Total operating expenses, plus depreciation, plus interest, minus } \\
\text { selling and administrative expenses, divided by annual hydrogen } \\
\text { sales. }\end{array}$ \\
\hline Cost of Goods Sold [\$] & $\begin{array}{l}\text { Total operating expenses, plus depreciation, plus interest, minus } \\
\text { selling and administrative expenses. }\end{array}$ \\
\hline $\begin{array}{l}\text { Earnings before Interest, Taxes, and } \\
\text { Depreciation [\$] }\end{array}$ & Total annual revenue minus total operating expenses. \\
\hline Gross Margin $\left[\$ / k g ~ H_{2}\right]$ & $\begin{array}{l}\text { Total revenues minus total expenses, discounted by the inflation } \\
\text { rate and divided by the total sales of hydrogen. }\end{array}$ \\
\hline Gross Margin [\$] & Total revenues minus operating expenses. \\
\hline Hydrogen Sales [kg H $\mathrm{H}_{2}$ /day] & Total annual hydrogen sales divided by the length of the year. \\
\hline Incidental Revenue [\$] & $\begin{array}{l}\text { Other station revenue enhancements from presence of hydrogen. } \\
\text { Expressed as marginal revenue minus marginal expenses. }\end{array}$ \\
\hline Investor Cumulative Cash Flow [\$] & Net investor contributions plus previous year investor contribution. \\
\hline Investor Equity [\$] & Total equity. \\
\hline Investor Equity Less Capital Incentive [\$] & Total equity minus capital incentives. \\
\hline Investor Net Cash Flow [\$/year] & Investor withdrawals minus investor contributions. \\
\hline Monetized Tax Losses [\$] & $\begin{array}{l}\text { Tax loss credits that could be applied when the majority equity } \\
\text { holder has tax liabilities in excess of any credits. }\end{array}$ \\
\hline Net Income [\$] & $\begin{array}{l}\text { Revenues, minus operating expenses, minus interest expense, } \\
\text { minus taxes payable, minus depreciation expense. }\end{array}$ \\
\hline Net Issuance of Debt [\$] & $\begin{array}{l}\text { Cash flow associated with acquisition of debt financing, or } \\
\text { associated with repayment of debt. In the case of revolving debt, } \\
\text { repayment is done in full at the end of the equipment's lifetime. }\end{array}$ \\
\hline Net Issuance of Equity [\$] & $\begin{array}{l}\text { Cash flow from or to equity investors (i.e., investment, dividends, } \\
\text { or owner withdrawals). }\end{array}$ \\
\hline Production Incentive [\$] & Annual revenue derived from production incentives. \\
\hline Receipt of One Time Capital Incentive [\$] & Cash flow from receipt of capital incentives, grants, or tax credits. \\
\hline Station Utilization [\%] & $\begin{array}{l}\text { Annual dispensed hydrogen divided by design annual capability. } \\
\text { Design capacity hinges on no excessive customer wait times } \\
\text { during peak demand during the year. }\end{array}$ \\
\hline Total Expenses $\left[\$ / \mathrm{kg} \mathrm{H} \mathrm{H}_{2}\right]$ & $\begin{array}{l}\text { Total expenses discounted by the inflation rate, divided by the } \\
\text { total sales of hydrogen. }\end{array}$ \\
\hline Total Revenues [\$/kg H $\left.\mathrm{H}_{2}\right]$ & $\begin{array}{l}\text { Total revenues discounted by the inflation rate, divided by the total } \\
\text { sales of hydrogen. }\end{array}$ \\
\hline
\end{tabular}


Five additional results are presented as numerical values at the upper right. The internal rate of return (a percentage) is the annualized, nominal (i.e., not inflation-adjusted), leveraged (i.e., accounting for earnings leveraging via debt financing), after-tax effective return rate on investor contributions. The break-even hydrogen price is the real hydrogen price at which the net present value of investor contributions would have been zero at a $10 \%$ after-tax discount rate. The first year positive EBITD is the first year the value for total annual revenue minus total operating expenses becomes positive. The investor payback period is the number of years required for positive cumulative cash flow to occur. The NPV is the net present value of investor contributions, based on the discount rate.

You can download a spreadsheet of the results by clicking the "Download Results CSV" button in the lower right corner of the web tool. 


\section{Example Cases}

This section briefly presents three cases to illustrate aspects of the H2FAST web tool's functionality.

\subsection{Default Case: Net Issuance of Equity and Debt}

Figure 2 shows the tool's default case with graphs for net issuance of equity and debt selected via the drop-down menus. The default case is a nominal near-term station with gaseous tank truck delivery and $250 \mathrm{~kg} /$ day capacity. Default values should be updated with the best cost estimates available for a particular project to attain case-specific results. As the graphs show, debt (a loan) and equity (funds from equity investors) are issued in the first year, dividends are paid annually after the second year, and the revolving debt is repaid in the final year.

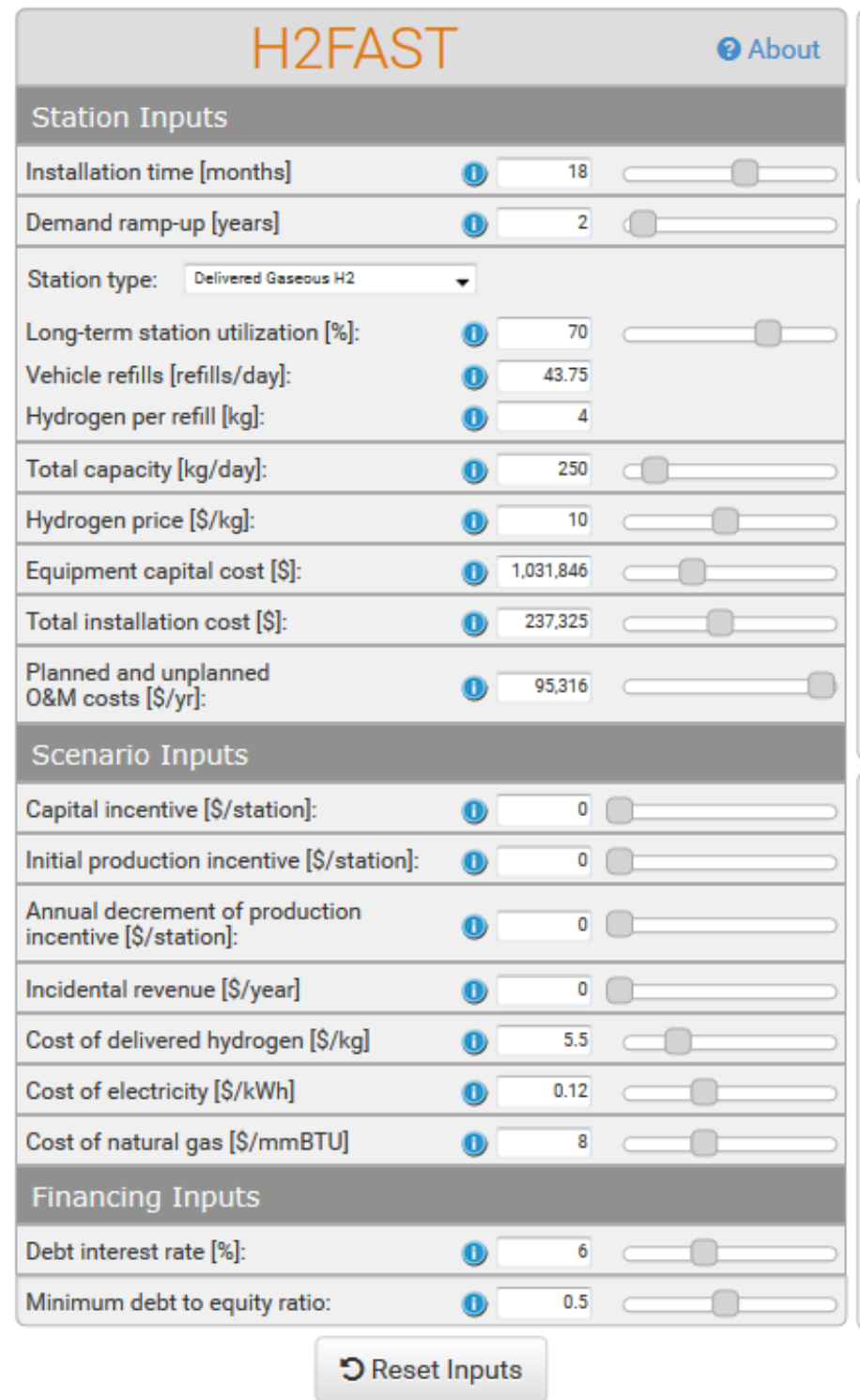

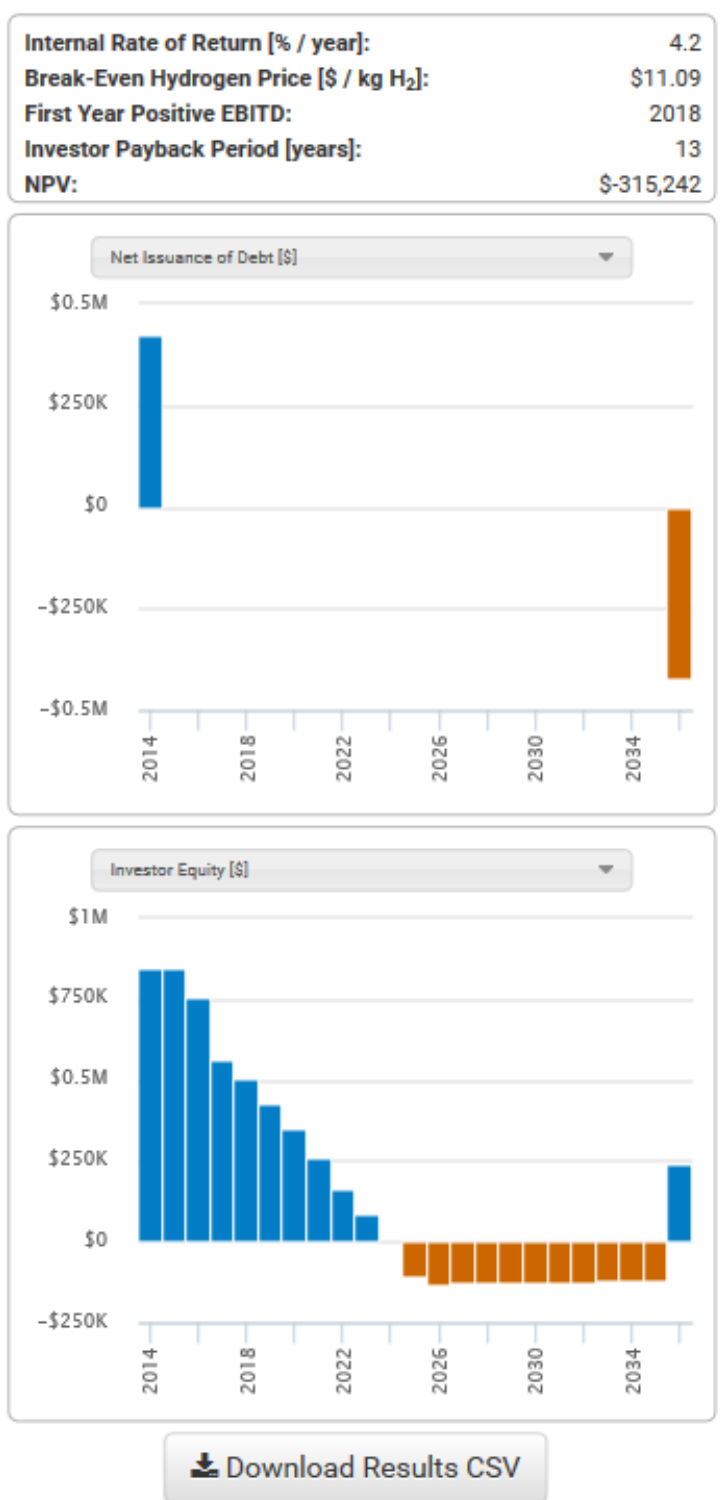

Figure 2. Default case with plots of the issuance of equity and debt 


\subsection{Capital Incentive}

Figure 3 shows a case with a capital incentive set at $\$ 1,000,000$ for the station. The graphs in Figure 3 are set to show cumulative cash flow and the one-time capital incentive. The internal rate of return has risen to $32.5 \%$ (from $4.2 \%$ in the default case), and the payback period has decreased to 4 years (from 13 years in the default case).

\begin{tabular}{|l|l|l|l|}
\hline & \\
\hline
\end{tabular}

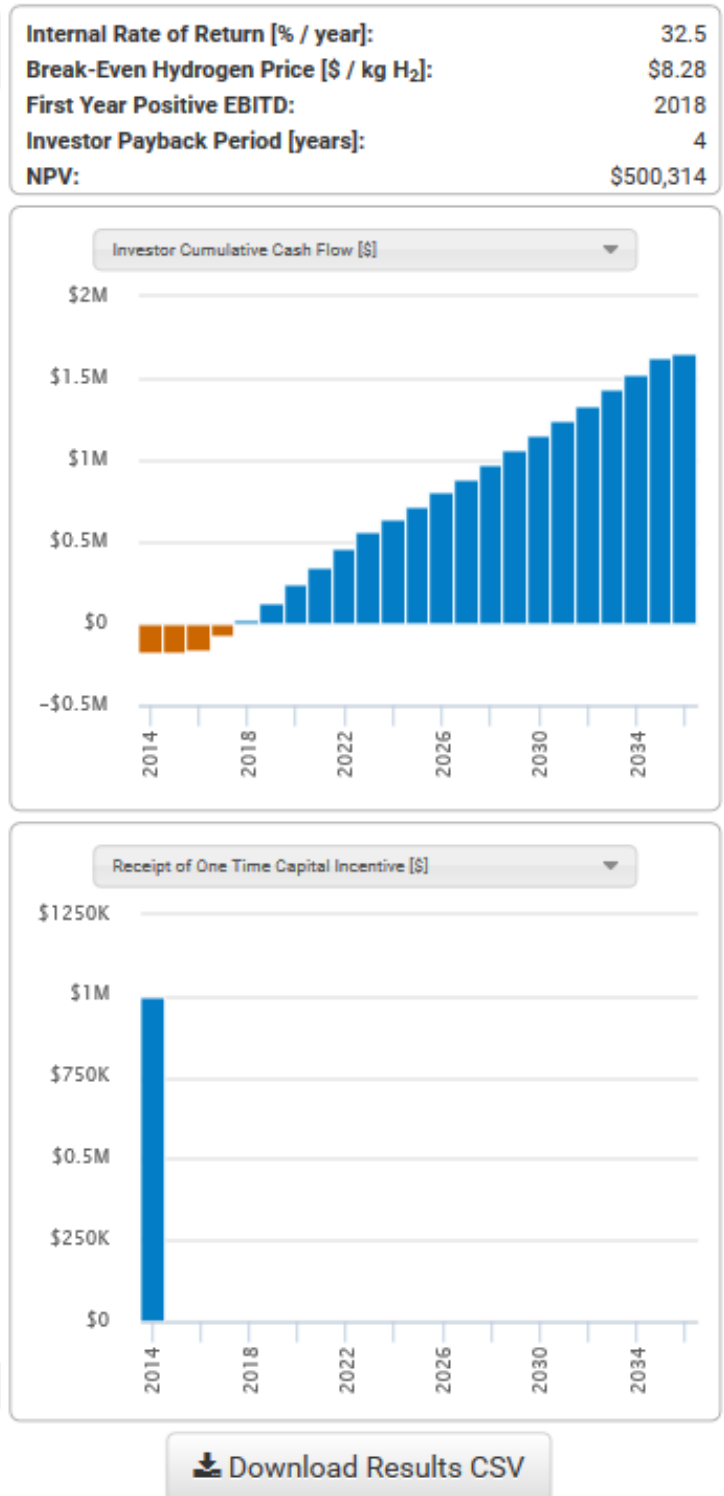

Figure 3. Example capital incentive case with plots of investor cumulative cash flow and the capital incentive 


\subsection{Production Incentive Instead of Capital Incentive}

Figure 4 shows a case with an annually decreasing production incentive and no capital incentive. The capital incentive field is set to zero, the production incentive field to $\$ 100,000$, and the annual decrement field to $\$ 10,000$; this represents a hypothetical production incentive that starts at $\$ 100,000$ in the first year the station is online and decreases by $\$ 10,000$ each subsequent year. The graphs in Figure 4 are set to show cumulative cash flow and the production incentive. The internal rate of return has dropped to $10.4 \%$ (from $32.5 \%$ in the capital incentive example case), and the payback period has increased to 7 years (from 4 years in the capital incentive example case).

\begin{tabular}{|c|c|c|c|}
\hline \multicolumn{2}{|c|}{ H2FAST } & \multicolumn{2}{|r|}{ (2) About } \\
\hline \multicolumn{4}{|l|}{ Station Inputs } \\
\hline Installation time [months] & (1) & 18 & \\
\hline Demand ramp-up [years] & (1) & 2 & \\
\hline Station type: Delivered Gaseous $\mathrm{H}_{2}$ & 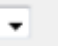 & & \\
\hline Long-term station utilization [\%]: & (c) & 70 & \\
\hline Vehicle refills [refills/day]: & (1) & 43.75 & \\
\hline Hydrogen per refill [kg]: & (1) & 4 & \\
\hline Total capacity [kg/day]: & (1) & 250 & \\
\hline Hydrogen price $[\$ / \mathrm{kg}]$ : & (1) & 10 & \\
\hline Equipment capital cost [S]: & (1) & $1,031,846$ & $\lessdot 0$ \\
\hline Total installation cost [\$]: & (1) & 237,325 & \\
\hline $\begin{array}{l}\text { Planned and unplanned } \\
\text { O\&M costs [\$/yr]: }\end{array}$ & (1) & 95,316 & \\
\hline \multicolumn{4}{|l|}{ Scenario Inputs } \\
\hline Capital incentive [S/station]: & (1) & 0 & \\
\hline Initial production incentive [\$/station]: & (1) & 100,000 & \\
\hline $\begin{array}{l}\text { Annual decrement of production } \\
\text { incentive [\$/station]: }\end{array}$ & (1) & 10,000 & \\
\hline Incidental revenue [S/year] & (1) & 0 & \\
\hline Cost of delivered hydrogen [S/kg] & (1) & 5.5 & $\leftarrow 0$ \\
\hline Cost of electricity [\$/kWh] & (1) & 0.12 & \\
\hline Cost of natural gas [S/mmBTU] & (1) & 8 & \\
\hline \multicolumn{4}{|l|}{ Financing Inputs } \\
\hline Debt interest rate [\%]: & (1) & 6 & $\square 0$ \\
\hline Minimum debt to equity ratio: & (1) & 0.5 & $\square 0$ \\
\hline
\end{tabular}

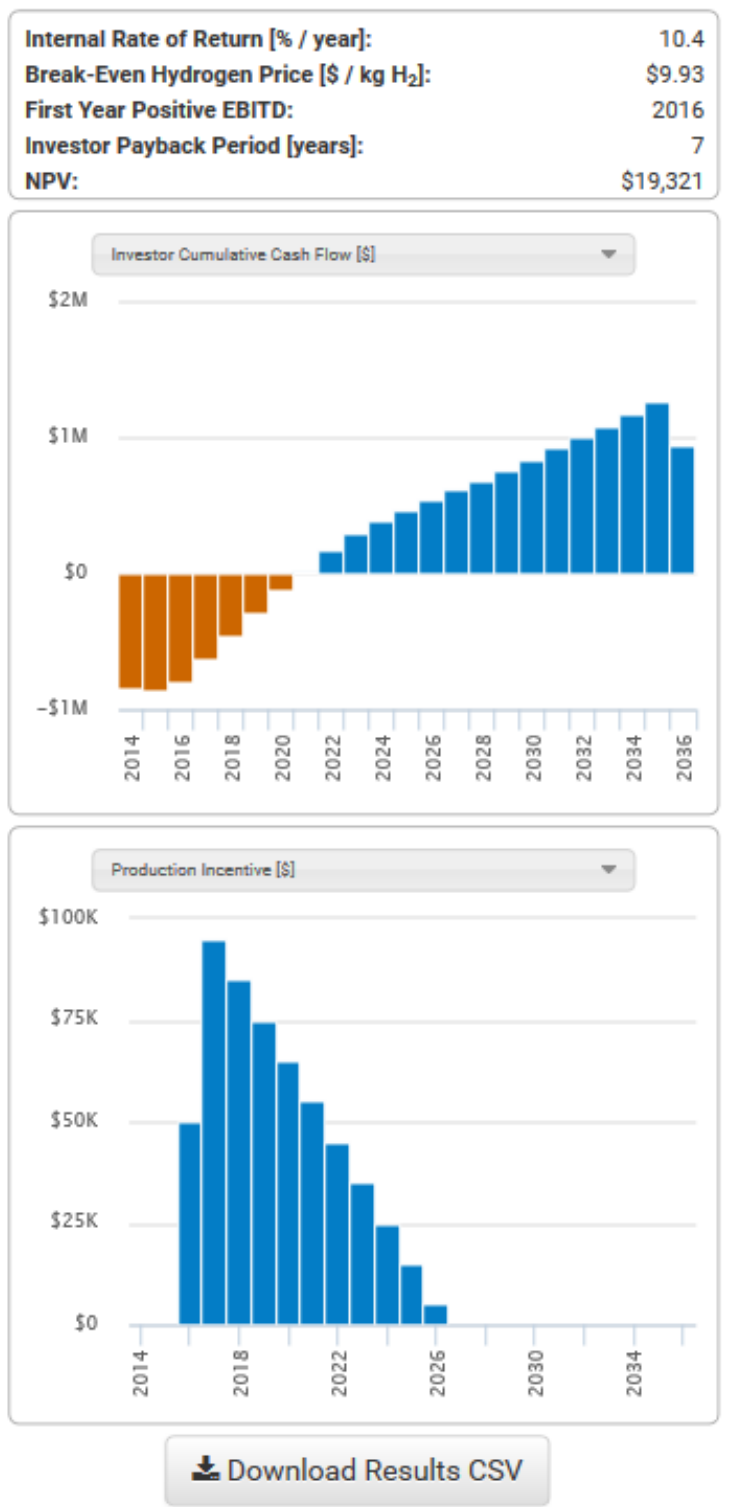

Figure 4. Example case with a production incentive instead of a capital incentive 


\section{Frequently Asked Questions (FAQs)}

\section{Can I expand the input fields or change the types of results displayed?}

Because the H2FAST online tool is designed for quick and easy analysis of hydrogen station finances, its inputs are limited to the fields shown. Its results are limited to the graphs listed in Table 2 as well as the five numerical values described in Section 2.2. However, a spreadsheetbased version of H2FAST has substantially more functionality, including many more inputs and the ability to display numerous financial results. You can download the spreadsheet tool at www.nrel.gov/hydrogen/h2fast/.

\section{How do I restore H2FAST's default values?}

To restore the default values, simply use your browser's refresh/reload function or click the "Reset Inputs" button.

The hydrogen price I entered under Station Inputs is greater than the break-even price in the results, yet my final cumulative cash flow is negative. Why does this happen?

The break-even hydrogen price is the price at which the net present value would be zero. Although that price is closely related to the price at which cumulative cash flow is zero, the break-even price is not identical to that value.

Why is there often a large jump in net cash flow (up or down, depending on the inputs) in the final year of the analysis period?

The dispensing equipment reaches the end of its useful life in the last year of the analysis period, and the station is less than fully utilized that year as the equipment is retired, while other expenses persist throughout that year.

\section{What is the difference between hydrogen price and break-even hydrogen price?}

Hydrogen price is the sales price of hydrogen, including all taxes and other charges. It is specified by the user as an input. Break-even hydrogen price is what that sales price of hydrogen would have to be for the net present value of the investment to be exactly zero. It is computed by H2FAST.

\section{What is the dispensing pressure at the refueling station?}

The H2FAST tool does not make assumptions about pressures. The pressure and other engineering parameters are implicit in the cost data that the user chooses to enter into the tool. Stations can be modeled for either 700 bar for light duty vehicles or 350 bar for buses. Users can specify a station's capital cost, maintenance, and energy use in accordance with the specific station they have in mind (700 bar or 350 bar).

\section{How reliable is the internal rate of return computation?}

In many cases there are multiple solutions to the internal rate of return equation. H2FAST only reports one of these solutions (the one with the smallest absolute value).

\section{Does H2FAST report real dollars or nominal dollars?}

H2FAST reports nominal dollars. 


\section{Technical Support}

If you have questions or comments about the web-based H2FAST tool, please email the H2FAST developers at $\underline{\mathrm{H} 2 \mathrm{FAST} @ \text {,nrel.gov. }}$ 


\section{References}

ANL (Argonne National Laboratory). (2015). "H2A Refueling Station Analysis Model (HRSAM) Version 1.0." Accessed March 25, 2015:

http://www.hydrogen.energy.gov/h2a delivery.html.

DOE (U.S. Department of Energy). (2015). "DOE H2A Analysis: Production Case Studies." Accessed March 25, 2015: http://www.hydrogen.energy.gov/h2a prod studies.html.

EIA (U.S. Energy Information Administration). (2015). “Annual Energy Outlook 2014.” Accessed March 16, 2015: http://www.eia.gov/forecasts/aeo/.

FASAB (Federal Accounting Standards Advisory Board). (2014). FASAB Handbook of Federal Accounting Standards and Other Pronouncements, as Amended. Washington, DC: Federal Accounting Standards Advisory Board.

Investopedia. (2014). “Accounting (Fundamental Analysis) Terms.” Accessed December 2014: http://www.investopedia.com/categories/accounting.asp.

Melaina, M.; Penev, M. (2013). Hydrogen Station Cost Estimates: Comparing Hydrogen Station Cost Calculator Results with other Recent Estimates. NREL/TP-5400-56412. Golden, CO:

National Renewable Energy Laboratory. http://www.nrel.gov/docs/fy13osti/56412.pdf. 


\section{Appendix: Quick Facts about Hydrogen Fueling}

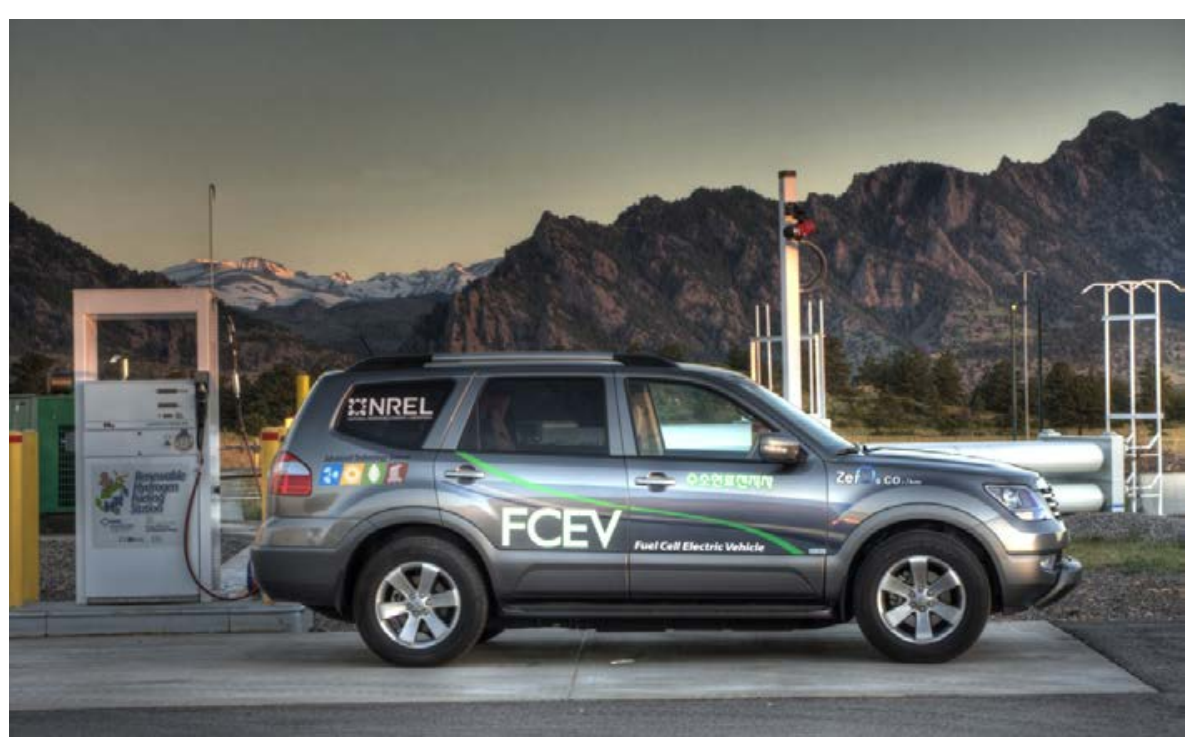

Photo by Chris Ainscough, NREL 19512

\section{Hydrogen}

\section{Sources of hydrogen}

\section{Energy equivalence}

Cost per kilogram of hydrogen

Conversion of natural gas via steam methane reforming is the primary means of producing hydrogen today. Onsite production by electrolysis is also used for smaller demands. Future systems may include gasification of biomass, large-scale electrolysis using wind, or direct conversion using solar, coal, or nuclear resources.

The energy in 1 kilogram of hydrogen is approximately equivalent to the energy in 1 gallon of gasoline.

Because a fuel cell electric vehicle is about twice as efficient as a similar conventional gasoline vehicle, an owner can drive twice as far on a kilogram of hydrogen than on a gallon of gasoline. Therefore, if the hydrogen price is $\$ 10 / \mathrm{kg}$, the cost to the owner would be equivalent to about $\$ 5 /$ gal gasoline on a cost-per-miledriven basis.

\section{Fuel Cell Vehicles}

Onboard hydrogen storage methods
Compressed hydrogen at 5,000-10,000 psi (near term); other options include liquid hydrogen and hydrogen stored on or in other materials

$300+$ miles

〜-6 kilograms

\section{Hydrogen Stations}

12

33

California (18), New York (5), Michigan (4)
Public stations open

Private stations open

States with most stations
Data sources: Alternative Fuels Data Center (www.afdc.energy.gov/fuels/hydrogen.html),
FuelEconomy.gov (www.fueleconomy.gov). Station statistics are as of May 8, 2015. 